\title{
Communicating Domains of Change in Nigeria's Niger Delta
}

\author{
Uwem Akpan \\ Department of Communication Arts, University of Uyo, Uyo, Akwa Ibom State, Nigeria \\ Phone: 08023560755, E-mail: uwemikang@yahoo.com
}

KEYWORDS Most Significant Change. Sustainable Livelihoods. Community Participation. Post-amnesty

\begin{abstract}
For a region that has witnessed criminality, wars and other forms of violence as well as deprivation, environmental degradation and general lack of development, the Niger Delta appears to be on the threshold of a new lease of life following the grant of presidential amnesty which has been accepted by the warring militants. The amnesty has come with a declaration by government to address the myriad of problems in the Niger Delta so that the seeming peace in the region can endure. This article is of the view that for the intervention by government to be successful, the benefiting communities should be involved in the decision-making, that is, should be involved in setting the priorities of intervention, since the prevailing conditions of each community are different. In effect, the prevailing conditions of each community should play a major role in the nature of intervention by government. The paper argues that change(s) in the lives of the people should be as attested to by the beneficiaries, and not government, and that such change(s) should cut across political, cultural, social, economic and ecological well being.
\end{abstract}

\section{INTRODUCTION}

A densely populated area in Nigeria, the Niger Delta Region has steadily grown in its indispensability and centrality to the survival and wellbeing of Nigeria as a nation. The region's importance stems from its abundant oil reserves as well as issues relating to the exploitation and use of the oil wealth. While on one hand it offers the petroleum and gas resources with which Nigeria sustains herself, the Niger Delta Region, on the other hand, is a hotbed of conflict of different dimensions, and sometimes based on varying reasons. The issues that have come to define the complexion of the Niger Delta Region - an accumulation over the years - are many, deep and varied, and have so far been stubborn to solutions. What is seemingly incontrovertible is that successive administrations have not demonstrated the will, and, perhaps, sincerity, to address the monumental problems in the Niger Delta. Confronted by the enormity of the issues which elicit attention, many administrations have often ducked and considered it safer to let the sleeping dog lie. Courson (2009) in a study of the Movement for the Emancipation of the Niger Delta (MEND) and violence in the region said "attacks by MEND and other armed groups have led to the loss of a quarter of Nigeria's daily oil export since 2006. This has adversely affected the revenue base of the Nigerian government, profit margins of international oil companies operating in the region, and disrupted global supplies, contributing to rising prices in the volatile oil markets."
Somehow, the tide appears to be changing. The Umaru Musa Yar' Adua Administration braved the odds to confront the problems in the Niger Delta with the offer of unconditional amnesty and a pledge to tackle the accumulated problems. The presidential amnesty has thus opened a fresh chapter in the effort to address the many thorny issues in the region, with a view to providing a more decent form of living to people in the area. The unconditional pardon, which lasted from August 6 to October 4, 2009, appears to be the most serious attempt so far to address years of unrest which has taken a toll on both human and material resources of the nation.

The amnesty is coming amidst fears and doubts that government is cajoling the militants to give up arms to facilitate the resumption of oil exploitation activities, while there may not be any concrete commitment to develop the impoverished region. Beyond the normal government claims to invest huge sums of money in the region, there should be certain ways in which the promised (and expected) change(s) in the region should be measured. The kernel of this paper is that the people of the region as the main beneficiaries of the hoped-for government intervention programmes and policies should experience a change or changes which they would freely and happily communicate or recount. It is not a change recounted through the megaphones of government but by the beneficiaries themselves. The people of the Niger Delta, as those who have borne the brunt of years of neglect, deprivation and degradation, are the ones to declare that there have been positive changes in their lives, changes 
that they consider most significant. In other words, how is change communicated, and by whom in the post-amnesty Niger Delta region? Furthermore, how significant is the communicated change in the lives of the Niger Deltans?

\section{GEOGRAPHY}

The Niger Delta, cartographically and historically, is made up of the present-day Akwa Ibom, Bayelsa, Cross River, Delta, Edo and River States. They form the South-South Region. Geographically, the Niger Delta is divided into three sections:

(i) Western Niger Delta - this consists of the western section of the South-South which includes Delta and Edo States.

(ii) Central Niger Delta - this consists of the central section of the coastal South-South which includes Bayelsa and Rivers States.

(iii) Eastern Niger Delta - this consists of the Eastern or Atlantic section of the coastal South-South which includes Akwa Ibom and Cross River States.

However, Government in 2000 politically defined the Niger Delta Region to include Abia, Imo and Ondo States. The region covers an area of about $70,000 \mathrm{~km}^{2}$ and makes up $7.5 \%$ of Nigeria's land territory. It is inhabited by about 31 million people, accounting for more than $23 \%$ of Nigeria's total population.

The Niger Delta is multi-state and multi-ethnic. The Ibibio, Ijaw, Urhobo, Itsekiri, Edo, Igbo, Yoruba are some of the dominant groupings in the region. It has the largest wetland in Africa and maintains the third largest drainage basin on the Continent. The Delta's environment can be broken down into four ecological zones: coastal barrier islands, mangrove swamp forests, fresh water swamps, and lowland rainforests. The region is a well endowed ecosystem and it contains one of the highest concentrations of biodiversity on the planet, in addition to supporting abundant flora and fauna as well as arable terrain that can sustain a wide variety of crops, lumber of agricultural trees, and more species of fresh water fish than any ecosystem in West Africa. The large expanses of mangrove forests are estimated to cover approximately 5,000 to $8,580 \mathrm{~km}^{2}$ of land.

The Niger Delta derives its name from River Niger which flows eastwards from Guinea. The third longest river in Africa (after the Nile and the Congo) with a length of $4,180 \mathrm{~km}$, the Niger forms a wide fan-shaped delta, dividing into dozens of channels that wind through a maze of swamps and low lying islands as it empties itself into the Atlantic Ocean.

\section{THEORETICAL FRAMEWORK}

This work adopts a combination of models, primary among them the Most Significant Change (MSC) model. Other models are the Community Participation model and Sustainable Livelihood model. The MSC model was developed by Davis (1996) in Bangladesh as means of monitoring changes in development. It is a communication strategy which focuses on monitoring intermediate outcome and impact. According to Davis and Dart (2005), "the process involves the collection of significant change stories emanating from the field level, and the systematic selection of the most significant of these stories by panels of designated stakeholders or staff." The Most Significant Change model is an appreciative inquiry which Davis and Dart (2005) defined as "a package of approaches used to study organizational change and community development".

The model looks at both positive and negative changes, but essentially focuses on the positive change in the society. The MSC model is participatory in its monitoring and evaluation it involves the very people who are experiencing the significant changes; the changes so recorded or documented are the opinions of community members who are the beneficiaries of intervention programmes. This model enables government, development partners, non-governmental organisations and the communities in the Niger Delta to track the actual change that has taken place in the region following the cessation of hostilities and the acclaimed full scale attention to develop the Niger Delta. The use of the model would, to a great extent, sift facts from fiction, and test the claims to intervention made by government after the cessation of militancy in the Niger Delta.

This work combines the MSC model with the Community Participation model which the UN Report (1979) defined as "sharing by people in the benefits of development and involvement of people in decision making at all levels of society".

It also uses the Sustainable Livelihood model which is concerned with both material and non- 
material well-being of rural dwellers. Hence, change in the Niger Delta should be viewed from the point of the beneficiaries in both material and non material well being. Chamber and Conway (1991), cited by Zoomers (2008), stated that:

Livelihood comprises the capabilities, assets (including both material and social resources) and activities required for a means of living. A livelihood is sustainable when it can cope with and recover from stresses and shocks and maintain or enhance its capabilities and assets both now and in the future, while not undermining the natural resource base.

The livelihood approach is multi-disciplinary, and acknowledges that poverty is not merely economic, but involves political, cultural, social and ecological aspects as well. According to Zoomers (2005), the livelihood approach is founded in these capitals: "human capital (skills, education), social capital (networks), financial capital (money), natural capital (land, water, minerals), and physical capital (houses, livestock and machinery)."

Changes in the Niger Delta are not to be looked at from a narrow prism, but from a broader perspective that covers all aspects of living. These changes are ascertained, not by government, but by the beneficiaries who are also participants in the process of change and development. This implies that the beneficiaries should be involved in the setting of priorities of intervention according to their prevailing conditions, since, truly speaking, all conditions are not the same in all parts of the Niger Delta. The combination of these approaches will make the tracking of change easy, visible, transparent and measurable.

\section{PREVAILING CONDITIONS IN THE NIGER DELTA}

The prevailing conditions in the Niger Delta are direct consequences of the geography of the region as well as the exploitation of the natural resources of the region. The conditions are summarized below:

\section{(i) Oil Spills}

According to Wikipedia (2009), the Niger Delta Region

has witnessed the slow poisoning of the waters of this country and the destruction of vegetation and agricultural land by oil spills which occur during petroleum operations.

Oil spills occur due to a number of causes, including: corrosion of pipelines and tankers (accounting for $50 \%$ of all spills), sabotage (28\%), and oil production operations (21\%), with $1 \%$ of the spills being accounted for by inadequate or non-functional production equipment...A reason that corrosion accounts for such a high percentage of all spills is that as a result of the small size of the oilfields in the Niger Delta, there is an extensive network of pipelines between the fields as well as numerous small networks of flow lines...In onshore areas, most pipelines and flow lines, which have an estimate life span of about 15 years, are old and susceptible to corrosion.

\section{(ii) Impact on the Mangrove Forests}

A large part of the vegetation of the Niger Delta is mangrove forest, and it is estimated to cover about between 5,000 and $8580 \mathrm{~km}^{2}$ of land. A combination of activities such as poor land management and pollution from oil and gas has had tremendous impact on vegetation in the region such that a sizeable part of the mangrove forests is gradually disappearing. This directly affects the habitat structure and the input of energy through photosynthesis in the area. Above all, according to Science in Africa (2007), oil (and gas) pollution is known to acidify the soils, halt cellular respiration and starve roots of vital oxygen.

\section{(iii) Absence of Critical Infrastructure}

The Niger Delta is one of the least developed regions in Nigeria. This is in spite of the wealth it provides for the nation, the advocacy for the provision of infrastructure and the endless claims to commitment by government to the development of the region. The region lacks enough and quality schools, roads, bridges, hospitals, potable water and other amenities - a situation which directly undermines the contributions of the region to the national purse. The result is a life that epitomizes poverty, neglect and despondency. These conditions are in sharp contrast with the opulence and profligacy that are constantly displayed at the national and state capitals as well as the major cities and towns. There is so much imbalance 
in the distribution of wealth to the disfavour of the region.

\section{(iv) Gas Flaring}

According to Wikipedia (2009),

Nigeria flares more natural gas associated with oil extraction than any other country on the planet with estimates signifying that of the 3.5 billion cubic feet $\left(100,000,000 \mathrm{~m}^{3}\right)$ of associated gas produced annually, 2.5 billion cubic feet $\left(70,000,000 \mathrm{~m}^{3}\right)$ or about $70 \%$ in wasted via flaring. This equals about $25 \%$ of the UK's total natural gas consumption and it is equivalent to $40 \%$ of the entire African Continent's gas consumption in 2001. Associated gas wasted during flaring is estimated to cost Nigeria $\$ 2.5$ billion a year.

According to Friends of the Earth (2009), despite regulations introduced 20 years ago to outlaw the practice, most associated gas is flared, causing local pollution and contributing to climate change.

\section{(v) Criminality}

Deplorable conditions in the Niger Delta as a result of neglect and decades of oil and gas exploration have, naturally, led to frustrations on the part of the local populace. These frustrations have found expressions in various forms of criminality such as kidnapping and hostage-taking, destruction of oil facilities, murder and outright war, such that the Niger Delta has become a hot spot. Until recently when the presidential amnesty came into effect, the Niger Delta was a theatre of war between local militia groups - and there were many of them - and federal troops, with the people living under war conditions. Militancy became a channel for self- expression and self-preservation.

\section{DOMAINS OF CHANGE IN THE NIGER DELTA}

Davies and Dart (2005) stated that "domains are broad and (sometimes) fuzzy categories of possible significant change stories". In other words, domains have to do with categories from which the significant changes can be viewed and assessed. The authors outline four principal areas in which changes in the lives of people can be looked at: (i) changes in the quality of people's lives;

(ii) changes in the nature of people's participation in development activities;

(iii) changes in the sustainability of people's organizations and activities; and

(iv) any other changes.

The aforementioned domains should be specific, measurable, achievable, relevant and timebound (SMART). By implication, the indicators of change should be defined in a way that everyone interprets them in the same way. Thus, government at all levels, NGOs as well as the communities in the Niger Delta should have the same idea or understanding of what indicators to look for, in attempting to ascertain if, indeed, government acclaimed intervention programmes have had any positive impact on the lives of the people.

Those domains that are sometimes deliberately fuzzy do not detract from the SMART element. They are fuzzy to the extent that communities are allowed space to determine what, really, would constitute a change to them. This, then, calls for interactions, and frequently too, between the benefiting communities of government programmes and the government itself, ascertaining what the community would want to happen in their lives. This implies that categories of change are further determined by the prevailing conditions in a particular area. For example, change in one area may be the cessation or elimination of acid rain as result of gas flaring; in other areas, it could be the provision of water or health or educational facility or even a road infrastructure.

The issue then arises why domains of change are determined in advance. This is done to:

i) Provide guidance concerning the types of change needed or desired.

ii) Help government, the communities and other stakeholders to track progress in the specified area of intervention.

The other change category allows space for the reporting of change that does not fit into the named domains.

It is natural, and not contrary to expectations, that changes in the Niger Delta after the guns have ceased to boom, at least for now, should be positive. Yet the promise of government intervention does not translate automatically into better living for the people. Hence, some changes could turn out to be both unexpected and negative, and far from the much expected positive change. It is, therefore, necessary to monitor both 
the desired and undesired changes. Changing conditions may determine whether or not the militants would pick the gauntlet one more time - and with the active support of the Niger Delta communities.

Much as domains are defined, the period during which the monitoring of change is carried out should also be defined. Monitoring involves a periodic collection of information, but the frequency may vary. Given the urgency for development in the Niger Delta, the need arises for periodic monitoring of 6 months, 12 months, 18 months or above, depending on what domain of change is targeted. High frequency of monitoring may drain the purse though, yet it helps to keep track of events and easily highlight achievements or derailment or failure.

Defining the monitoring period is in line with SMART earlier related, as it provides the timeframe within which to measure the targets so far achieved. But it is important that the intervening agency - government - should set the targets, not the benefiting communities. Aside from its control of the resources, the government, through its specialized agencies and personnel, has access to relevant information that will guide it to determine the time-frame within which measurable targets can be achieved. Once the defining period has been set, it now becomes easy for government to work towards the target. Other participants are also alerted on the need to watch out for bottlenecks which government may deliberately build in to frustrate the achievements of targets.

\section{COMMUNITY PARTICIPATION: AN INEVITABLE PROCESS}

For government's intervention programmes in the Niger Delta to succeed, the ultimate beneficiaries should be involved through community participation. Often times, well intended programmes fail because of lack of public support for them. The United Nations Report (1979) defined community participation as "sharing by people in the benefits of development, active contribution by people to development and involvement of people in decision-making at all levels of society". Stiefel (1981) viewed community participation in the light of "organized efforts to increase control over resources and regulative institutions in given social situations on the part of the groups and movements hitherto excluded from such decision-making process". The key elements in community participation are taking part, influence and power (Desai 2005). It is necessary that the people in the Niger Delta are made integral stakeholders in the new push for development in the region, without which the implementation of the intervention programmes may become difficult.

This model of development, though not without shortcomings, is actively encouraged by international agencies and institutions such as the World Bank, the United Nations, National Governments, Non Governmental Organisations (NGOs) etc. Community participation, as Desai (2008) puts it, is essentially "actions by the poor to influence decision-making through direct and informal means", and this has emerged as "an alternative way by which they can gain access to decision making processes and to resources, and thereby improve their well being". Much as the intervention programmes and policies are mainly executed by government which controls the resources (which are rather scarce), communitybased organizations, (CBOs), NGOs and community leaders constitute the immediate stakeholders within the Niger Delta communities which government should encourage and demand their participation in the bid to breathe a new lease of life into an otherwise environmentally suffocated, poverty-ridden area. The involvement of these stakeholders has been lacking because policies and programmes for the Niger Delta are often crafted by persons who are alien to the region, persons who do not have a first hand experience of the problems there and who, in most cases, are cushioned in the comfort of their offices in the nation's capital.

The prevailing situation weighs heavily against the poor, such that although the Niger Delta produces the resources that sustain the nation, most people in the region hardly benefit from it. Desai (2008) captured the situation aptly:

The poor, since they have neither socioeconomic nor political power, do not generally gain access to the decision making processes and hence are unable to influence them. Therefore, the poor have not benefitted from economic growth, but have in fact have become worse off.

The implementation of community participation is not without hiccups. Government may find the process a convenient opportunity to subvert and manipulate the people to achieve the intent 
of political actors. It may decide to engage in co-optation and clientelism. (Desai 2008) expatiated on this, with a warning though:

Co-optation may occur when community leaders believe, often mistakenly, that formal affiliation will further the interests of those whom they represent by providing better access to the agencies distributing resources. Political parties and government departments may be eager to co-opt leaders as a means of extending their influence over local constituencies. The community may lose its autonomy and become subject to the orthodox of the co-opting body...The other form of support is based on clientelism. A patron-client relationship is an enduring dyadic bond, based on informally arranged personal exchanges of resources between actors of unequal status. In the case of the poor communities, the leader or 'broker' maintains a personal relationship with the politicians or administrators, who control limited resources required by the community or members of the community...The leader or patron benefits in so far as he is able to demand the loyalty of those dependent on him and to mobilize that loyalty on behalf of his supervisor. Clients benefit as long as they gain access to influential people who may intercede on their behalf and increase the chances of a successful outcome to their demand making.

These possible abuses notwithstanding, community participation demonstrates that people can form partnerships with governments, development agencies, NGOs etc. to bring about development and poverty reduction in the Niger Delta. It emphasizes the oft-made point that the people of the Niger Delta have a right to participate in decision-making which directly affects their living conditions.

\section{CONCLUSION}

The importance of the Niger Delta Region to the survival of Nigeria as a viable and indivisible state has created a new sense of urgency to bring stability to the area. Without stability, the region will continue to be a hot spot where violence and various forms of crimes hold sway. However, the grant and acceptance of the presidential amnesty has, for now, reduced tension in the area. Yet it has created a new dimension of fears - fears that the amnesty may not hold, as government may not keep to its bargain of bring- ing development to that traumatized region. As Oyefusi (2010) concluded in his study entitled, "Oil and the Probability of Rebel Participation among Youths in the Niger Delta of Nigeria", "strategies to achieve a long lasting civil peace in Nigeria's Delta must go beyond grievance to address individual-level factors that determine the opportunity cost of participation in violence, such as low income level and low educational attainment, and community-level factors that create an opportunity to profit from extreme forms of civil disobedience".

For the silence of the once-booming gun to metamorphose into permanent peace, there is need for government intervention in the area to be concrete, and changes experienced to be measurable. Such intervention should have the community (the beneficiaries) as participants who are part of the decision-making in the process of bringing development to their community. They should determine their priorities according to their areas of need, as a result of their prevailing conditions. They should also be the ones, not government, to share information that following government intervention, change has, indeed, come into their lives.

\section{REFERENCES}

Chambers R, Conway G 1991. Sustainable Rural Livelihoods: Practical Concepts for the 21st Century. Discussion Paper 296, Institute of Development Studies.

Courson E 2009. Movement for the Emancipation of Niger Delta Political Marginalization, Repression and Petroinsurgency in the Niger Delta (online). From <www. njas.helsinki.fi/pdf-files/vol11 num3/william_02.pdf> (Retrieved on July 28, 2011)

Davies R 1996. An Evolutionary Approach to Facilitating Organizational Learning: An Experiment by the Christian Commission for Development in Bangladesh (online). From <http://www.mande.co. uk/docs/ccdb.htm> (Retrieved April 2005).

Davies R, Dart J 2005. The Most Significant Change (MSC) Technique: A Guide to Its Use. A Research funded by CARE International, United Kingdom and eight other international agencies.

Desai V 2008. Community participation in development. In: V Desai, R Potter (Eds.): The Companion to Development Studies. London: Hodder Education, pp. 115-119.

Friends of the Earth 2009. Gas Flaring in Nigeria (online). From<http://www.foe.co.uk/resource/mediabriefing/ gasflaringinNigeria.pdf $>$ (Retrieved on September 18, 2009).

Oyefusi A 2010. Oil and the Probability of Rebel Participation among Youths in the Niger Delta of Nigeria (online). From<http://www.prio.no/upload/prio/ Oil $\% 20$ and $\% 20$ probability $\% 20$ of $\% 20$ rebel $\% 20$ 
participation\%20among \%20Youths\%20in\%20the $\% 20 \mathrm{Niger} \% 20$ Delta\% of 20Nigeria.pdf $>$ (Retrieved on July 28,2011$)$.

Science in Africa 2002. Indigenous Plants to the Rescue (online). From<http:/www.africanconservation.org/ ncftemp/nipa.html> (Retrieved on May 21, 2007).

Stiefel M 1981. Editorial. In: Dialogue About Participation, I. Geneva: United Nations Research Institute for Development.
United Nations 1979. 1978 Report on the World Situation. New York: United Nations.

Wikipedia, The Free Encyclopaedia 2009. Environmental Issues in the Niger Delta (online). From $<$ http:// www.google.com> (Retrieved on September 18, 2009)

Zoomers A 2008. Rural livelihoods. In: V Desai, R Potter (Eds.): The Companion to Development Studies. London: Hodder Education, pp.147-151. 